\title{
THE TELEFITTING METHOD USED IN THE NATIONAL NETWORK OF TELEAUDIOLOGY: ASSESSMENT OF QUALITY AND COST EFFECTIVENESS
}

\author{
Arkadiusz Wasowski ${ }^{1,2}$, Henryk Skarzynski ${ }^{1,2}$, Artur Lorens ${ }^{1,2}$, Anita Obrycka ${ }^{1,2}$, \\ Adam Walkowiak ${ }^{1,2}$, Piotr H. Skarzynski ${ }^{1,3}$, Andrzej W. Wlodarczyk ${ }^{1,2}$, Lukasz Bruski ${ }^{3}$ \\ ${ }^{1}$ Institute of Physiology and Pathology of Hearing, ul. Zgrupowania AK "Kampinos" 1, 01-943 Warszawa, Poland \\ ${ }^{2}$ World Hearing Center, ul. Mokra 17, Kajetany 05-830 Nadarzyn, Poland \\ ${ }^{3}$ Institute of Sensory Organs, ul. Mokra 1, Kajetany 05-830 Nadarzyn, Poland
}

Corresponding author: Arkadiusz Wasowski, World Hearing Center, Auditory Implants and Perception Department, Kajetany, Mokra 17, 05-830 Nadarzyn, Poland

\begin{abstract}
Background: To obtain the best hearing benefits after cochlear implantation, the speech processor must be optimally fitted. The majority of patients have to undertake a long trip to the cochlear implant (CI) clinic, and this incurs high cost, time, and travel weariness. To overcome this problem, 'telefitting' has been proposed. The aim of this paper is to present the results of a large-scale introduction of telefitting into clinical practice.
\end{abstract}

Material and Methods: Material of this study consisted of 94 cochlear implant users scheduled for telefitting between March and May 2011 in one of 8 centers selected for this study. For cost assessment a group of 195 patients was surveyed.

Each patient underwent a teleconsultation procedure. After telefitting the patient was presented with a questionnaire consisting of questions relating to the quality and time effectiveness of telefitting and the preparation process, assessment of the ease of contact with the audiologist, the sense of security and calm during the session, and an overall assessment of its usefulness as an alternative to different kinds of standard visits.

Results and Conclusions: The Nationwide Network of Teleaudiology proved to be a reliable platform for telefitting. The method and a proposed model of postoperative care for implanted patients using telemedicine seems to be a reliable alternative to standard model. It improves the quality of service provided to patients and saves substantial time and money.

Key words: telemedicine $\bullet$ telefitting $\bullet$ cochlear implant

\section{EL MÉTODO TELEFITTING UTILIZADO EN LA RED NACIONAL DE TELEAUDIOLOGÍA: EVALUACIÓN DE LA CALIDAD Y LA RENTABILIDAD}

\section{Resumen}

Antecedentes: Para obtener los mejores beneficios de la audición después de la implantación coclear, el procesador del habla debe ser óptimamente ajustado. La mayoría de los pacientes tienen que emprender un largo viaje para la clínica del implante coclear (IC), y esto incurre en altos gastos, el tiempo y el cansancio de viaje. Para superar este problema, se ha propuesto 'telefitting. El objetivo de este trabajo es presentar los resultados de una introducción a gran escala de telefitting en la práctica clínica.

Materiales y métodos: El material de este estudio consistió en 94 usuarios de implantes cocleares con el telefitting programado para las fechas de entre marzo y mayo de 2011 en uno de los 8 centros seleccionados para este estudio. Para la evaluación de los gastos se examinó un grupo de 195 pacientes. Cada paciente se sometió a un procedimiento de teleconsulta. Después del telefitting se presentó al paciente un cuestionario que constaba de preguntas relativas a la calidad y la eficacia de tiempo de telefitting y al proceso de preparación, la evaluación de la facilidad de contacto con el audiólogo, el sentimiento de seguridad y calma durante la sesión, y una evaluación general de su utilidad como una alternativa a otros tipos de visitas estándar.

Resultados y Conclusiones: La red nacional The Nationwide Network of Teleaudiology demostró ser una plataforma fiable para el telefitting. El método y el modelo propuesto de los cuidados postoperatorios sobre los pacientes implantados utilizand telemedicina parece ser una alternativa fiable para el modelo estándar, ya que mejora la calidad del servicio prestado a los pacientes y ahorra mucho tiempo y dinero.

Palabras clave: telemedicina $\bullet$ telefitting $\bullet$ implante coclear 


\section{AJUSTEMENT A DISTANCE DE FONCTIONNEMENT DE L'IMPLANT COCHLEAIRE, METHODE UTILISEE DANS LE RESEAU NATIONAL D'AUDIOLOGIE A DISTANCE: EVALUATION DE LA QUALITE ET DU COUT.}

\section{Résumé}

Contexte: Pour obtenir les meilleurs résultats auditifs après implantation cochléaire, le processeur vocal doit être ajusté de manière optimale. La majorité des patients doivent alors effectuer un long voyage jusquà la clinique d'implants cochléaires, et cela entraîne un coût élevé, prends du temps, et engendre de la fatigue due au voyage. Pour surmonter cette difficulté, la méthode de l'ajustement à distance a été proposée. Le but de cet article est de présenter les résultats à grande échelle de l'ajustement à distance de l'implant cochléaire dans la pratique clinique.

Matériel et méthodes: Cette étude s’est basée sur 94 utilisateurs d'implants cochléaires bénéficiant d'un ajustement à distance entre Mars et Mai 2011 et ce dans l'un des 8 centres sélectionnés pour cette étude. Pour l'évaluation des coûts, un groupe de 195 patients a été étudié. Chaque patient a été reçu en téléconsultation. Après chaque ajustement à distance, le patient a du remplir un questionnaire composé de questions relatives à la qualité, à l'efficacité et à la préparation de cette consultation ainsi que sur l'évaluation de la facilité de contact avec l'audiologue, le sentiment de sécurité et de calme au cours de la session, et une évaluation globale de son utilité comme une alternative aux différents types de visites classiques.

Résultats et Conclusions: Le réseau national Polonais de télé-audiologie s’est avéré être une plate-forme fiable pour l'ajustement à distance du fonctionnement de l'implant cochléaire. La méthode et le modèle de soins postopératoires proposé pour les patients implantés en utilisant la télémédecine semble être une alternative fiable au modèle standard. Il améliore la qualité du service offert aux patients et permet d'économiser beaucoup de temps et d'argent.

Mots clés: télémédecine • ajustement à distance du fonctionnement de l'implant cochléaire • telefitting • implant cochléaire

\section{МЕТОД УДАЛЕННОЙ ПОДГОНКИ, ПРИМЕНЯЕМЫЙ В НАЦИОНАЛЬНОЙ СЕТИ ТЕЛЕАУДИОЛОГИИ: ОЦЕНКА КАЧЕСТВА И ЭКОНОМИЧНОСТИ}

\section{Краткий обзор}

История вопроса: Для получения оптимальных результатов после кохлеарной имплантации процессор распознавания речи должен быть тщательным образом подогнан. Большинство пациентов вынуждены преодолевать большие расстояния до клиники в целях проведения кохлеарной имплантации (CI), что сопряжено с большими финансовыми расходами, потерей времени и утомительными переездами. Для решения данной проблемы была предложена стратегия «удаленной подгонки». Цель данной работы - ознакомить с результатами масштабного внедрения удаленной подгонки в клиническую практику.

Материалы и методы: В исследовании принимали участие 94 пользователя кохлеарных имплантатов, которым была назначена удаленная подгонка в период с марта по май 2011 г. в одном из 8 центров, выделенных для данного исследования. В целях оценки экономичности была обследована группа из 195 пациентов. Каждый пациент прошел процедуру удаленной консультации. После удаленной подгонки пациенты получили анкету с вопросами, связанными с качеством и выигрышем во времени процедуры удаленной подгонки, а также подготовительного процесса, оценкой доступности связи с сурдологом, чувством защищенности и покоя в ходе сеанса и общей оценкой полезности метода в качестве альтернативы стандартным визитам различного типа.

Результаты и Заключения: Национальная сеть телеаудиологии была признана надежной основой для удаленной подгонки. Метод и предложенная модель послеоперационного лечения пациентов с имплантатами с применением удаленных медицинских процедур признана надежной альтернативой стандартной модели. Метод повышает качество обслуживания пациентов и позволяет достичь экономии времени и средств.

Ключевые слова: удаленная медицина • удаленная настройка • кохлеарный имплантат

\section{Background}

To obtain hearing benefits after cochlear implantation it is crucial to provide well organized post-operative care for the patient. One of the most important tasks during this procedure is to optimally fit the cochlear implant system. It is usually done according to a specific fitting procedure, requiring an experienced, multidisciplinary team to undertake repeated sessions with the patient in the cochlear implant (CI) clinic. For the majority of patients these 
visits require long travels from their home, which is often associated with high cost, time, and travel weariness, which limits the reliability of the test results and the fitting outcomes. Moreover, a rapid increase in the number of cochlear implant recipients in recent years, and projected further development in this area, make managing the procedure more difficult.

One solution to address the aforementioned problems is to transfer some parts of the procedure to smaller, cooperating centers spread around the country. These centers are usually sufficiently equipped and have teams ready to provide medical and rehabilitation care at a satisfactory level. However, some parts of the procedure, like psychophysical measurement or programming of cochlear implant system, cannot be conducted by those teams due to a lack of trained specialists and limited experience. To overcome this problem, the use of telemedicine has been proposed. It allows cooperating polyclinics to conduct part of the procedure consisting of ENT examination, audiological tests, and rehabilitation evaluation. At this point, experienced specialists from the CI clinic, supported by local staff, perform the final part of the procedure: psychophysical and objective measurements, and speech processor programming.

The basis of this approach has in recent years already been described [1-3]. The Internet allows specialists from the CI clinic to set up a teleconference for audio and video contact with the patient and support specialist, and allows remote desktop software to access a remote computer and perform measurement and fitting. This method has been assessed under controlled conditions in which patients undergo a fitting procedure twice: in standard face-to-face mode and in simulated remote mode, usually performed in the same building, but using telemedical technology. Those studies proved telefitting to be safe, reliable, and well accepted by both patients and specialists. Electrical stimulation parameters obtained during telefitting did not differ greatly from values obtained during standard, face-to-face fitting.

However, it is difficult to find results of the introduction of the proposed method into clinical practice, especially for patient assessment of the "real life" quality of the service that has no backup of a second, standard fitting. In addition, estimates of the cost and time savings that can be obtained in real life are missing.

\section{Aim}

The aim of this paper is to present the results of a largescale clinical introduction of telefitting into clinical practice, based on experiences gained during day-to-day use of the National Network of Teleaudiology.

\section{Material and Methods}

\section{Material}

Material of this study consists of 94 cochlear implant users that were scheduled for telefitting between March and May 2011 in one of 8 centers in Poland. The whole network consists of 20 centers, and 8 were selected for the purpose of this study. Inclusion criteria also included the patient's ability to reliably assess the course and outcome of telefitting and be able to fill in questionnaires, so only adults and older children able to meet these requirements were included. Mean age of the patient was 34.5 years, median 30.5 years, $\mathrm{SD}=16.9$, and the range varied from 12 to 86 years. Mean experience with the cochlear implant system (time from first fitting) was 57 months, median 48 months, $\mathrm{SD}=42$ months, with the range varying from 6 months to 17 years. They were users of different cochlear implant systems: $73.4 \%$ with MED-EL devices, $23.4 \%$ with Cochlear devices, $3.2 \%$ with Advanced Bionics devices.

For cost assessment, a group of 195 patients was selected from one of 5 representative polyclinics distributed throughout Poland. Out of the selected group, 41 were from the region of Podkarpackie, 38 from Pomorskie, 46 from Warminsko-Mazurski, 29 from Slaskie, and 41 from Zachodniopomorskie.

\section{Method}

The National Network of Teleaudiology was introduced in 2009 , with the aim of providing a wide range of telehealth applications like telefitting, telediagnostics, telerehabilitation, or teleeducation. It consists of 20 cooperating centers in Poland and 1 in the Ukraine (Figure 1). The center of the network is the International Center of Hearing and Speech in Kajetany, from where experienced specialists provide telecare for patients in cooperating polyclinics. Every node is equipped with HDX8006 teleconference terminals from Polycom Inc. with 32" LCD screens, zoomable and movable Polycom cameras, connected to a system with $2 \mathrm{Mbit} / \mathrm{s}$ symmetrical Internet connections. In every node there is a PC computer equipped with clinical interface boxes with appropriate fitting software and speech therapy software. The 'Logmein.com' application is used to provide remote desktop functionality. Some 41 support specialists were trained in cooperating centers. During the telefitting procedure they were responsible for helping in the communication process and in basic technical tasks like connecting the speech processor to the interface.

Each patient underwent a teleconsultation procedure developed for cochlear implant users and introduced into clinical practice in the National Network of Teleaudiology. The aim of the procedure was to closely emulate the standard procedure used during face-to-face visits in the CI clinic. The teleconsultation procedure includes ENT examination, preparation stage, and telefitting itself. During the preparation stage, a support specialist does a structured interview with the patient concerning hearing benefits, communication skills, and usage schemes in daily life. The next step is psychoacoustic measurements - freefield audiometry and speech audiometry with monosyllabic words in quiet and noise (SNR 10dB), according to the patient's skills. The last stage of preparation is consultation with a local speech therapist, when hearing and communication problems can be addressed.

During the second part - telefitting - a specialist from the CI clinic discusses with the patient and the support speech specialist the results of the questionnaire. Then the speech processor is connected to the interface by the support specialist, and the fitting specialist takes control of the remote computer. Objective measurements are then performed: impedance, ECAP, and/or ESR measurements according 


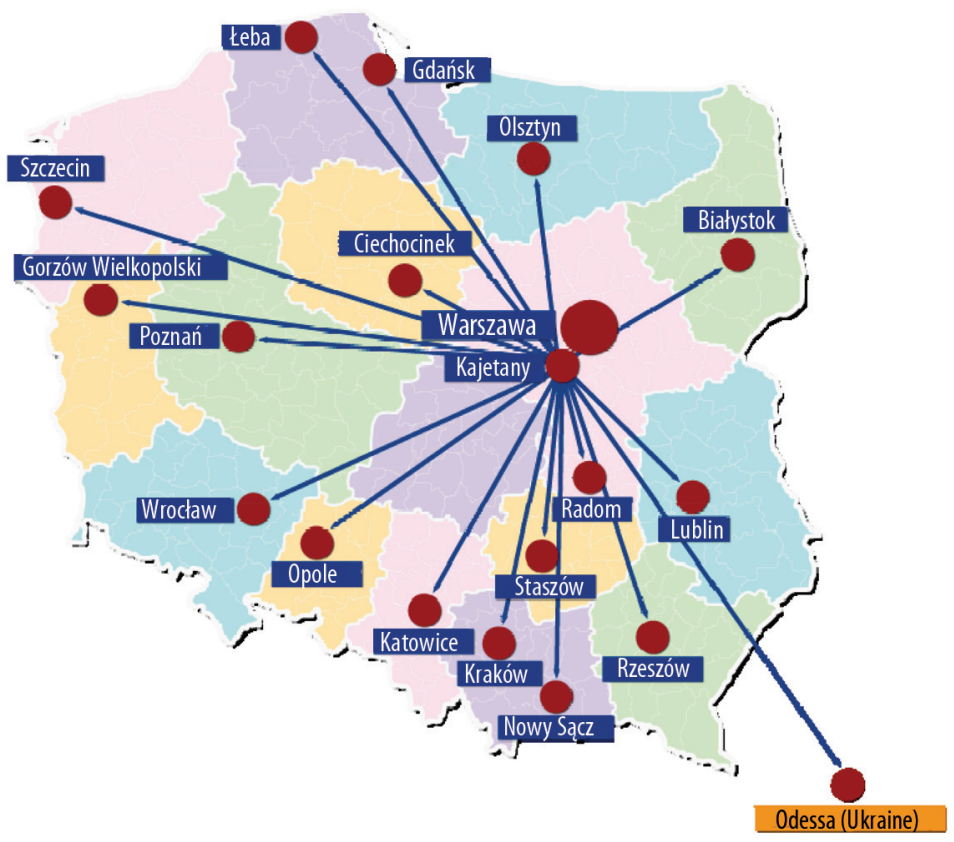

Figure 1. The National Network of Teleaudiology.

Table 1. Questionnaire results.

\begin{tabular}{|c|c|c|c|c|c|}
\hline & $\begin{array}{l}\text { Strongly } \\
\text { disagree }\end{array}$ & Disagree & $\begin{array}{l}\text { Neither } \\
\text { agree nor } \\
\text { disagree }\end{array}$ & Agree & $\begin{array}{l}\text { Strongly } \\
\text { agree }\end{array}$ \\
\hline Quality of audio-video connection is good & 0 & 4 & 1 & 33 & 56 \\
\hline I had good contact with audiologist & 0 & 2 & 5 & 35 & 52 \\
\hline I felt safe and secure during telefitting & 0 & 1 & 3 & 33 & 57 \\
\hline $\begin{array}{l}\text { I'm satisfied with the course and effects of } \\
\text { telefitting }\end{array}$ & 0 & 0 & 5 & 38 & 51 \\
\hline Telefitting is an alternative for standard fitting & 0 & 0 & 4 & 32 & 58 \\
\hline Telefitting allowed for saving in time and money & 0 & 0 & 3 & 22 & 69 \\
\hline
\end{tabular}

to the needs of the particular patient. The next step consists of psychophysical measurements like the amplitude growth function, threshold detection, or MCL evaluation, with the task difficulty adjusted to the patient's capabilities. The final step is creation of the new program and a live mode when the first feedback is obtained from the patient. In all steps the support specialist is actively involved. Usually ENT examination and the preparation stage take 1 hour and telefitting takes from 45 minutes to 1 hour.

After telefitting, the patient is presented with a questionnaire consisting of questions relating to quality and time effectiveness of telefitting and preparation process, assessment of ease of contact with the audiologist, sense of security and calm during the session, and overall assessment of its usefulness as an alternative to different kinds of standard visits.

The commuting time and distance that the patient would have to go using their car to get to the International Center of Hearing and Speech versus one of the satellite clinics was calculated on the basis of residential addresses of the patient and address of the institution. Google Maps was used in the survey. Then the distance calculated was multiplied by a standard kilometer rate for the use of a private car (with an engine capacity of $900 \mathrm{~cm}^{3}$ ) for professional purposes (as specified in the 2007 regulation set by the Minister of Infrastructure). The result is the basis for calculating the amount of time and money saved in cases where a patient decides to use remote fitting of the speech processor.

\section{Results}

The results of the patient assessments are presented in Table 1. In most cases patients agreed or strongly agreed to questions relating to good quality of the audio-video connection and contact with the audiologist. In 4 out of 5 cases where quality of the audio-video connection was not assessed as good, contact with the audiologist was rated poorer and the patient's feeling of security was not satisfactory. We can assume that in those subjects overall communication ability was limited. In general, patient satisfaction from the course and outcome of telefitting was high, although in 5 
Table 2. Overall assessment.

\begin{tabular}{|l|c|c|c|}
\hline & No & Have no opinion & Yes \\
\hline Telefitting is a good alternative for first fitting & 21 & 42 & 31 \\
\hline Telefitting is a good alternative for standard follow-up & 3 & 5 & 86 \\
\hline I'm going to use telefitting in the future & 0 & 6 & 88 \\
\hline
\end{tabular}

cases patients neither agreed nor disagreed with this statement. However, only 2 out of those 5 did not agree that telefitting was a good alternative for standard visits. Another 2 cases who did not agree with this statement answered "agree" or "strongly agree" for other questions. In 3 cases there were no apparent saving of time or money due to unexpected complications on the way to a subsidiary clinic.

Table 2 presents an overall assessment by the patients of the new procedure. The majority agreed that telefitting was a good method for standard follow-up visits, but only in 31 cases did they agree that it should be used for a first fitting, reaffirming what the authors believe that first fitting should be done in the traditional way. Overwhelmingly, $93 \%$ of patients would use telefitting in the future, with only 6 out of 94 not sure and none disapproving.

Patients were also asked for assessment of the time saved if they were to consult a satellite clinic closer to their home. The mean time saved by patients would be 10.5 hours, with $\mathrm{SD}=8.85 \mathrm{~h}$. Minimum time saved was reported as $40 \mathrm{~min}$ utes, maximum 48 hours.

A cost reduction assessment, performed for the larger group of 195 patients, revealed that the mean saving was $12.5 \%$ of the mean average national salary. The same analysis showed that mean reduction travel time was 8 hours 19 minutes, which for some reason is different from the value obtained from patient questionnaires. The authors believe that the reason for the difference is rounding done by patients during filling in of the questionnaires, including the amount of time for resting and sometimes staying overnight after the visit in the implantation clinic and increases caused by traffic.

\section{Discussion}

The Nationwide Network of Teleaudiology, as introduced into clinical practice in the Institute of Physiology and
Pathology of Hearing, has proved to be a reliable platform for telefitting. The method and proposed model of postoperative care of implanted patients seems to be a reliable alternative to the standard model, improving quality of service for the patients and providing substantial time and money savings. At the same time, there may be patients who do not comfortably fit into the telemedical environment - for them the standard path of postoperative care should be followed.

The impact of the Nationwide Network of Teleaudiology on healthcare could be very large, allowing quality healthcare to be provided through telecommunications technology to underserved populations in Poland and abroad [4].

At present there is a large group of patients with levels of low frequency hearing which, in general, remains beyond the scope of effective treatment by currently available hearing prosthetic devices, including hearing aids and cochlear implants. The patients' low-frequency hearing, even when amplified, is grossly insufficient for communication in everyday life. This type of hearing loss has been termed "partial deafness" (PD) [5-7]. Such patients are not yet widely considered eligible for cochlear implantation because it is feared that intervention could damage their residual low-frequency hearing, and additionally they require more complicated fitting after surgery. In this situation, the Nationwide Network of Teleaudiology, removing the barrier of distance between patients and specialists with experience in PD treatment, and allowing for remote fitting, could contribute to a rapid growth in the number of candidates with PD. Telemedicine practitioners now have the potential to make a global impact on CI delivery.

The authors believe that the proposed method leads to an improvement in the quality of postoperative care after cochlear implantation, and the telefitting method could and should be a part of normal clinical practice.

\section{References:}

1. Wesarg T, Wasowski A, Skarzynski H et al: Remote fitting in Nucleus cochlear implant recipients. Acta Otolaryngol, 2010; 130(12): 1379-88

2. Wasowski A, Skarzynski PH, Lorens A et al: Remote fitting of cochlear implant system. Cochlear Implants Int, 2010; 11(1): 489-92

3. Rodríguez C, Ramos A, Falcon JC et al: Use of telemedicine in the remote programming of cochlear implants. Cochlear Implants Int, 2010; 11(1): 461-64

4. Polovoy C: Audiology telepractice overcomes inaccessibility. The ASHA Leader, 2008; 13(8): 20-22
5. Skarzynski H, Lorens A, Piotrowska A: A new method of partial deafness treatment. Med Sci Monit, 2003; 9(4): CS20-24

6. Skarzynski H, Lorens A, Piotrowska A, Anderson I: Preservation of low frequency hearing in partial deafness cochlear implantation (PDCI) using the round window surgical approach. Acta Otolaryngol, 2007; 127: 41-48

7. Skarzynski H, Lorens A: Partial deafness treatment. Cochlear Implant Int, 2010; 11(Suppl.1): 29-41

8. Skarzynski H, Lorens A, Piotrowska A, Skarzynski P: Hearing Preservation In partial deafness treatment. Med Sci Monit, 2010; 16(11): CR555-62 